\title{
ANTITRUST ASPECTS OF TRANSATLANTIC INVESTMENT
}

\author{
Wilbur L. Fugate*
}

INTRODUCTION

by

Richard W. McLaren

Assistant Attorney General, Antitrust Division

United States Department of Justice

As indicated by Mr. Fugate in the following article, there can be no question that foreign investment is welcome in the United States. The new products, new technology, and new competition accompanying such investment can only be a plus for the American economy. Our antitrust laws have the task of maintaining a competitive economy, free from unduly restrictive practices or market domination, and in a period when growing concentration of economic power within the United States is becoming a matter of increasing concern, this task would be made considerably easier by the introduction of new sources of competition from abroad. The procompetitive philosophy behind our antitrust laws has been given a great deal of credit for the vigorous, imaginative, and flexible business spirit in our country.

Exclusionary or discriminatory business practices directed at foreign firms will be given no different treatment at the Antitrust Division or the Federal Trade Commission than when a U.S. firm is the victim. We have a duty to enforce the law with an even hand, and we, like other nations, will do everything we can to prevent deliberate violations of our law. In other words, in a very important sense, our antitrust laws are a distinct advantage to the foreign company doing business here.

In my opinion, foreign companies considering U.S. investment are unduly concerned about the effects of the U.S. antitrust laws in regulating their business activities. Aside from exemptions for particular regulated segments such as railroads and public utilities, the antitrust laws cover industry generally in the United States and are based on the idea of business freedom, the very antithesis of regulation. While the antitrust laws are firmly enforced and apply both to the interstate and foreign commerce of the United States, they are well charted, and, if in doubt, the businessman and his lawyer

* Chief, Foreign Commerce Section, Antitrust Division, U.S. Department of Justice. Member of the U.S. Delegation to the Organization for Economic Cooperation and Development Restrictive Business Practices Committee. Author, Foreign Commerce and the ANtitrust Laws (r958). 
can take advantage of our "Business Review Procedure" or a similar procedure in the Federal Trade Commission.

As Mr. Fugate notes in the instant article, our antitrust laws are not directed generally to the activities of foreign companies or even to the activities of U.S. companies ase they affect the citizens or economies of other countries. Instead, they apply extraterritorially only as to acts or agreements directly and substantially affecting U.S. foreign trade. While we have encouraged other nations in seeking economic freedom and fostering competition, we do not seek to force our laws or policies on other countries. It is for each country to choose its own path. For ourselves-and we note that we now have the company of many nations-we have chosen a free competitive enterprise economy under rules of law. It has been extremely successful in the United States.

$$
\text { **** }
$$

The tremendous surge of reciprocal direct investment on both sides of the Atlantic has been commented on at length in this symposium. Antitrust is one of the many legal problems which investors see as an unknown quantity, a complication, and sometimes a barrier to such investment.

The difficulty foreign businessmen have in understanding U.S. antitrust laws has substantially lessened with the advent of the wave of antitrust legislation throughout the world in the past twenty years. U.S. businessmen may feel more at home with these antitrust laws in other countries, but they are troubled as to the possibilities of conflict and being caught between two opposing sets of laws. It is the purpose of this article to attempt to put the antitrust laws in proper perspective from the viewpoint of the company contemplating investment here or abroad, and hopefully to give some reassurance that enforcement in the foreign area is reasonable as well as logical.

The subject necessarily is divided into a discussion of the U.S. antitrust laws as they affect foreign companies making direct investments in the United States and the application of these laws to the foreign operations of U.S. companies. These are, of course, very broad topics and must be treated here in somewhat summary fashion. ${ }^{1}$

\section{Foreign Investment In the United States}

U.S. policy, including antitrust, is to deal with foreign business in the United

\footnotetext{
${ }^{1}$ See generally K. Brewster, Antitrust and American Business Abrond (r958); W. Fugnte, Foretgn Commerce and the Antttrust Laws (I958); A. Neale, The Antitrust Laws of the United States ch. Io (I960); Report of the Atrorney General's National Committee to Study the Antitrust Laws 66-77 (1955); A.B.A. Antitrust Section, ANtitrust Developments 1955-1968, ch. 2 (ig68); Restatement (Second) of the Foreign Relations LaW of the United States $\$ \$$ i8, 19, 38, 39, 40 (1965); Nitschke, The Antitrust Laws in Foreign Commerce, 53 Mrch. L. Rev. 1059 (1955); Kramer, Application of the Sherman Act to Foreign Commerce, 3 Anritrusr BuLl. 387 (1958); Carlston, Antitrust Policy Abroad, 49 Nw. U.L. REv. 569 (1954).
} 
States on the same basis as U.S. business. Here we have none of the controversy referred to later as to the extraterritorial reach of the U.S. antitrust laws. Apparently no one contests the principle that a foreign company operating in the United States should, as to such domestic business, be amenable to U.S. laws, including the antitrust laws.

Foreign investment is welcomed, and the idea sometimes expressed abroad, that the United States enforces its antitrust laws to keep out or limit foreign investment, is absurd. On the contrary, when a foreign company is involved in antitrust problems, it is given every consideration. The Justice Department consults the Department of State as to possible foreign relations problems, even though the arrangement in question may be essentially a domestic one.

Non-national corporations may do business freely in the United States without any special restrictions. Licenses to do business, when required, are of a routine nature and are granted by the respective states normally without any differentiation between United States and foreign companies.

Only occasionally, where the federal government designates a special business having a particular U.S. interest, are American companies favored over nonnational companies. Presently, there are statutes and regulations which favor U.S. companies in the procurement of materials for the benefit of friendly foreign nations under grant or guarantee by the U.S. government. Such materials are paid for or financed by the Agency for International Development (AID) and the preference extends not only to the goods shipped abroad but also to the vessels carrying such goods. ${ }^{2}$

These preferences were the basis of the holding in the Concentrated Phosphate case $^{3}$ to the effect that such procurement and shipment abroad, since it was practically restricted to U.S. sources, was not "export" in the sense of the WebbPomerene Export Trade $\mathrm{Act}^{4}$ granting an exemption from the antitrust laws.

Aside from these unusual situations, a non-national company doing business in the United States has the same rights and obligations as a national company, including the obligation to obey the U.S. antitrust laws. There is no differentiation as to foreign companies in the enforcement of these laws. In fact sometimes, as in the Singer case, ${ }^{5}$ the decision may even appear to favor foreign companies at the expense of U.S. companies. ${ }^{6}$ Needless to say, this result also is not intended, but the

\footnotetext{
${ }^{3}$ See Foreign Assistance Act of $\mathrm{Ig} 6 \mathrm{I}, 75$ Stat. 427, as amended, 22 U.S.C. $\$ 2 \mathrm{I} 5 \mathrm{I}$ (I96I); 22 C.F.R. 5201 ( 1968 ).

${ }^{3}$ United States v. Concentrated Phosphate Export Ass'n, 393 U.S. r99 (I968).

40 Stat. 5 I7 (19:8), I5 U.S.C. $\$ 62$ (I964).

'United States v. Singer Mfg. Co., 374 U.S. I74 (I963).

'See id. at 196 , where the Court stated:

"It is strongly urged upon us that application of the antitrust laws in this case will have a signifiacntly deleterious effect on Singer's position as the sole remaining domestic producer of zigzag sewing machines for household use. . . Whether economic consequences of this character warrant relaxation of the scope of enforcement of the antitrust laws, however, is a policy matter committed to congressional or executive resolution."
} 
Department of Justice and the Federal Trade Commission both seek to enforce the antitrust laws in a fair and impartial manner.

A number of antitrust cases have involved foreign manufacturers (or their distributors) seeking to market their products in the United States by a noncompetitive distribution system. Just as in the case of domestic companies, some manufacturers or distributors of foreign-made products, including Volkswagen, ${ }^{7}$ Renault, ${ }^{8}$ Hambro, ${ }^{0}$ and Gestetner, ${ }^{10}$ to name a few, have run afoul of the antitrust laws in such matters as resale price fixing and dealer territorial restrictions.

There have not been many antitrust cases involving direct investment in the U.S. market by foreign companies. Two of these, however, have occasioned considerable comment in the European press. ${ }^{11}$

In the first case, termed the Mobay case, ${ }^{12}$ the Department of Justice brought suit in I964 under section I of the Sherman Act and section 7 of the Clayton Act against Monsanto Company in the United States and the Bayer Company of Germany, attacking their United States joint venture in the plastic foam industry. The Department noted at the time that these billion dollar companies were, respectively, the fourth and fifth largest chemical companies in the world and that eighty-five per cent of Bayer's sales volume was accounted for by chemical products which were also produced by Monsanto and which accounted for sixty-five per cent of Monsanto's sales volume.

The joint company involved produced isocyanates, a new and important product used in the production of urethane (plastic) foam. The complaint charged that prior to the formation of Mobay, the parents were both producing isocyanates, Monsanto within the United States and Bayer abroad, and that both were selling in the United States and in foreign markets. Accordingly, the companies were actual as well as potential competitors in the United States.

\footnotetext{
${ }^{7}$ United States v. Volkswagen of America Corp., I962 Trade Cas. para. 70,256 (D.N.J. xg62) (consent decree).

${ }^{8}$ United States v. Renault, Inc., r962 Trade Cas. para. 70,386 (S.D.N.Y. 1962) (consent decree).

${ }^{\circ}$ United States v. Hambro Automotive Corp., rg60 Trade Cas. para. 69,620 (S.D.N.Y. 1960) (consent decree).

${ }^{10}$ United States v. Gestetner Corp., r968 Trade Cas. para. 72,536 (S.D.N.Y. I968) (consent decrec).

${ }^{11}$ Another antitrust case involving an acquisition by a foreign company in the United States was United States v. Aluminium Ltd., 268 F. Supp. 758 (D.N.J. r966), r967 Trade Cas. para. 7I,895 (consent decree). The Justice Department brought suit against this large Canadian aluminum producer alleging that its acquisition, through its U.S. subsidiary, Alcan, of an aluminum fabricating division of National Distillers Company violated $\$ 7$ of the Clayton Act. The case, settled by a consent decrec calling for the sale of specified fabricating facilities (the court subsequently relieved the Canadian company from this obligation), was one of a series of cases attacking similar acquisitions by U.S. producing companies, which threatened the U.S. aluminum fabricating industry. Cf. United States v. Aluminum Co. of America (Alcoa-Rome), 377 U.S. 27I (1964). See generally: Sympositum, loint Ventures and Mergers in the Western Hemisphere, 32 ABA ANTrTRust L.J. I56-214 (1966); Scott \& Yablonski, Transnational Mergers and Joint Ventures Affecting American Exports, 14 AstrrRust BuLl. I (1969); Donovan, The Legality of Acquisitions and Mergers Involving American and Foreign Corporations Under the United States Antitrust Laws, 40 So. CaLif. L. Rev. 38, 42 (1967).

${ }^{12}$ United States v. Monsanto Co., I967 Trade Cas. para. 72,00r (D.C. Pa. 1967) (consent decrec).
} 
By the time the suit was filed Mobay had fifty per cent of the fast growing market in this plastic foam raw material, most of the remaining production being shared by the du Pont and Allied Chemical companies. The joint arrangement, according to the complaint, provided for the transfer of technical information within the field of the agreement by both parents to Mobay, including patent rights.

The publication Business Europe stated at the time that "[d]ozens of other European firms, with existing or contemplated joint ventures with U.S. companies, can learn much from this case about a serious problem of doing business in the U.S."13 However, it is submitted that this case attacking a joint venture between two direct competitors, giants in the chemical industry, should not be of concern to the usual European company considering direct investment in the United States. Joint ventures are not per se illegal in the United States, and the antitrust laws do not bar a foreign company from taking an American partner. A large foreign company would be well advised, however, not to seek a joint venture with a large American company in the same industry-and assuredly not without seeking clearance from the Department of Justice or the Federal Trade Commission. Such clearance procedures will be mentioned later.

The Mobay case was settled by a consent judgment pursuant to which Bayer bought out all of the assets of Mobay, so that the European company not only did not have to leave the United States market but obtained the entire joint venture itself, presumably a not too unhappy solution for Bayer.

A current merger case brought by the Department of Justice had aspects which concerned a large foreign company. In the Atlantic Richfield-Sinclair case, ${ }^{14}$ the complaint charged that the proposed merger of two major oil companies, Atlantic Richfield Company and Sinclair Oil Corporation violated section 7 of the Clayton Act, and the Department of Justice sought a preliminary injunction.

Atlantic, as noted by the court in that hearing, in order to avoid attack on the merger under the antitrust laws, proposed to sell off Sinclair's marketing properties in the northeastern states to a subsidiary of British Petroleum, Ltd., one of the world's largest oil companies but not a U.S. marketer. The court considered that this would resolve the case as to the northeastern market, since "the sale of Sinclair assets to BP would substitute a new and viable competitor for Sinclair in the Northeast."15 The court mentioned that BP had a substantial interest in one of the recent North Alaskan Slope crude oil discoveries, and stated that:

Indeed it is plain that BP and BP Ltd. regard this as an opportunity to enter the American market on a large scale and thus to interject a new and strong competitive factor into that [Northeast] market. ${ }^{16}$

\footnotetext{
${ }^{18}$ Business Europe, April 29, I964 (published by Business International, S.A.).

16 United States v. Atlantic Richfield Co., 297 F. Supp. I06I (S.D.N.Y. I969); 1969 Trade Cas. para. $72,7 \times 6$.

${ }^{15}$ Id. at 1068 .

${ }^{10}$ Id. at I068. There are important distinctions between the Mobay and the Atlantic Richfield-Sinclair-
} 
The court, however, found a reasonable probability that the Government at trial would succeed on the issue of probable lessening of competition in the southeastern states as a result of the proposed merger. In view of this finding, Atlantic, with the consent of the Department of Justice, also agreed to sell to BP Sinclair's marketing outlets in the southeastern states, with the case against Atlantic proceeding as to the midwest and Rocky Mountain states. The Department of Justice in its press release of March 3, I969, indicated its belief that sale to BP "would establish British Petroleum in the United States as a new, viable competitor."

These cases, rather than indicating any hostility toward foreign investment, show that foreign investment and foreign competition is welcomed in the United States. As previously noted, the Department, in cases like Singer, ${ }^{17}$ has taken very positive action to assure that foreign imports are not excluded by conspiratorial action by companies, domestic or foreign, already established in the American market.

\section{II}

\section{Investment Abroad by United States Companies}

The phenomenal rise in the past few years in U.S. direct investment abroad, particularly in Europe, has taken the form of expanding existing operations and establishing new foreign subsidiaries and affiliates or, alternatively, of acquiring interests in foreign companies or entering into joint ventures abroad with foreign companies.

There are no U.S. antitrust problems involved if a U.S. company independently establishes its own branch, subsidiary, or affiliate abroad. There may be antitrust problems if a joint factory is established by U.S. competitors, as in the Minnesota Mining case. ${ }^{18}$ There four-fifths of the abrasive industry, members of a WebbPomerene Export Trade Association, went beyond the antitrust immunities of the Webb-Pomerene Act, ${ }^{19}$ which are granted for engaging "solely in export trade." In that case, these companies combined to establish joint foreign factories (in Canada, Germany, and the United Kingdom) with a concert of action to marliet

B.P. situations. In Mobay, Bayer was already in the American market through exports and was the most likely large-scale entrant. This was a market for a new product, and, as in the Penn-Olin case (United States v. Penn-Olin Chemical Co., 378 U.S. 158 ( 1964 ), on appeal after remand, 389 U.S. 308 ( 1967 )), there were only a few producers and potential producers. The situation in the oil industry is quite different with many large integrated companies well established in the market. It appeared that BP was not a likely entrant into the petroleum market on the East Coast at any time in the near future. Its Alaskan discoveries would no doubt first be developed for the West Coast market.

Further, in the Mobay case, the joint venture put an end to any competition between the participants, Monsanto and Bayer. This was not true in the BP situation, since both Atlantic and, should the Government win the case, Sinclair, would be in competition with BP and there would be potential entry by both Atlantic and Sinclair into the East Coast market.

${ }^{17}$ United States v. Singer Mfg. Co., 374 U.S. r74 (rg63).

${ }^{18}$ United States v. Mininesota Mining \& Mfg. Co., 92 F. Supp. 947 (D. Mass. 1950).

${ }^{19}$ I5 U.S.C. $\$ 6 \mathrm{I}$ et seq. $(1964)$. 
from these joint factories rather than to export from the United States. Such action was held to be in restraint of U.S. foreign trade.

There may be antitrust problems encountered by a U.S. company in an acquisition of, or a merger or joint venture with, a foreign company. There have been relatively few antitrust cases in this area, and a former Antitrust Division head has said: "In the usual case of a merger or joint venture abroad, the primary impact would appear to be in the foreign country where the arrangement takes place."20 However, there may also be an impact on U.S. trade.

Some of the typical international cartel cases have also involved joint arrangements with foreign companies, such as in the ICI case. ${ }^{21}$ Even in that case, however, the court stated the rule that such joint ventures abroad are not illegal per se but their legality depends upon their purpose and effect. There, for example, the joint venture in the Canadian market between the American company, DuPont, and the British company, ICI, was found by the court to follow an old agreement to divide markets. The situation, as described by the court, was that an American company already established in the Canadian market and a British concern with a foothold in the same market had combined to jointly develop the market and pool their profits. The result was intended "to foreclose [DuPont] from the full development of its trade in Canada."22

Apart from such large scale agreements by major U.S. and foreign competitors not to compete, there are only a handful of cases involving acquisitions or joint ventures abroad. One fairly recent instance was the Schlitz case, ${ }^{23}$ where the American company, Schlitz Brewing Company, acquired a large interest in the large Canadian brewer, John Labatt, Ltd. While this acquisition was held illegal under section 7 of the Clayton Act primarily because actual, direct competition in the domestic market between Schlitz and General Brewing Co. of California, a U.S. subsidiary of Labatt, would be lessened, the court also mentioned the potential competition between Schlitz and Labatt itself. The court referred to the concentrated state of the beer market in the United States and stated that Canadian companies offered the greatest source of potential competition.

Potential competition was also at issue in the acquisition by Standard Oil Co. of New Jersey, which had large reserves of Canadian potash, of the Potash Company of America. The court felt that Standard with its Canadian reserves would have probably entered the North American market independently had it not acquired Potash of America. ${ }^{24}$

\footnotetext{
${ }^{20}$ See statement of former Assistant Attorney General Edwin M. Zimmerman in Hearings Before the Subcomm. on Antitrust and Monopoly of the Senate Judiciary Comm. on International Antitrust, 8gth Cong., 2 d Sess., pt. I, at 49 I (1966).

${ }^{21}$ United States v. Imperial Chem. Indus., Ltd., Ioo F. Supp. 504 (S.D.N.Y. I95I).

${ }^{22}$ Id at 557 .

${ }^{23}$ United States v. Schlizz Brewing Co., 253 F. Supp. 129 (D. Cal. I966), affd 385 U.S. 37 (1966), rehearing denied, 385 U.S. I02I (I967).

26 United States v. Standard Oil Co., 253 F. Supp. I96 (D.N.J. I966).
} 
In the pending Gillette case, ${ }^{25}$ the Justice Department has brought an action against the acquisition by the Gillette Company, the largest domestic producer and seller of safety razors and blades ("wet shaving" instruments), of Braun, A.G., the third largest manufacturer of electric razors ("dry shaving" instruments) in Europe. The complaint noted that Braun had entered into an exclusive distributorship and licensing arrangement in 1954 with the Ronson Corporation in the United States for the Braun-type electric razor, and that Ronson had been successful in an arbitration proceeding in 1967 in upholding the continuation of this agreement (until 1976 ), thus preventing Braun from selling and marketing this razor in the United States, itself or through another distributor. Ronson no longer acts as a distributor for Braun but manufactures this type of razor itself in the United States.

The complaint alleges that if the acquisition is permitted to stand, it will result in the elimination of Braun as a potential competitor in the U.S. market; competition between Gillette and Ronson, its domestic competitor, will be lessened; Gillette's dominant position in the U.S. market will be enhanced; and mergers and acquisitions by other manufacturers of shaving instruments will be fostered.

A case just filed by the Federal Trade Commission attacks the acquisition by Litton Industries, which in 1965 had acquired the second largest domestic typewriter company, Royal McBee Corporation, of the German typewriter company, TriumphAdler. ${ }^{26}$ The complaint alleges that Triumph-Adler is an actual as well as potential competitor in the U.S. market through its exports to the United States and distribution. The FTC press release states that "in recent years the principal source of new entry has been foreign typewriter producers."27

The few antitrust cases in this area of foreign acquisitions and joint ventures have applied to actual or potential competitors, the foreign party usually being a company which would be a direct competitor if in the United States. If such an arrangement abroad restricts U.S. imports, actual or potential, by the foreign company, then antitrust danger signals should be raised. It would appear equally logical that if actual or potential exports by the U.S. company are curtailed, antitrust problems are present.

\section{III}

\section{Extraterritorial Application of U.S. ANtitrust Laws}

For some reason hard to explain, the term "extraterritoriality" as applied to antitrust has been said to pose an unknown and mysterious threat both to foreign investment in the United States and to American operations abroad. ${ }^{28}$ It has been

\footnotetext{
${ }^{25}$ United States v. Gillette Co., Ig68 Trade Cas. para. 45,068 (D. Mass. Ig68).

${ }^{20}$ Litton Indus., Ltd., No. 8778 (F.T.C., April ro, 1969).

${ }^{37}$ FTC Press Release, April Ix, 1969. See also In the Matter of W.R. Grace \& Co., F.T.C. Docket C-1 ז82, Complaint filed March 9, I967.

${ }^{28}$ See Damm, The Economic Aspects of European Direct Investment in the U.S.A., and Ellis, Legal
} 
said to be an impediment both to foreign investment here and to American investment abroad. ${ }^{29}$

As to investment in the United States the fear has been expressed that if a foreign company invests here, it thereby submits its worldwide operations to the jurisdiction of U.S. courts and will run the risk that these courts "will arrogate unto themselves the power to dictate to that company what it must do and what it must not do outside the United States."30 This statement entirely misconceives the so-called extraterritorial basis of jurisdiction of the courts in antitrust cases. The Supreme Court has said many times that only those activities abroad which directly and substantially affect U.S. foreign commerce come within U.S. courts' jurisdiction under the antitrust laws. ${ }^{31}$ Even the acts of U.S. citizens and nationals abroad are outside of the scope of U.S. antitrust unless they have such an effect. Certainly, the acts of foreign companies abroad not affecting U.S. commerce are not brought within the antitrust laws merely because of the "presence" of the foreign company in the United States.

Conversely, if indeed the activities of foreign companies do restrain U.S. trade, they are not immune from such laws, and usually these restraints will bring sufficient contacts with the United States upon which jurisdiction may be founded.

The Senate Antitrust and Monopoly Subcommittee in its extensive and illuminating hearings on "International Aspects of Antitrust" considered the other charge-that the antitrust laws are actually an impediment to U.S. foreign trade. After considering some twenty alleged examples of such detriment, Senator Hart stated:

Some of the cases struck me as instances where, from the facts stated, there would have been no violation at all by the proposed conduct. In others, apparently, there would have been doubt.

One would have to get the full story before resolving the doubt, if it could be resolved, and somewhere it would appear that the argument could have been made only on the theory that competition ought to be restricted..$^{32}$

Professor James Rahl, an authority in this field, in an American Bar Association panel on antitrust and foreign trade last year stated that the idea of the U.S. antitrust laws as a detriment to U.S. foreign trade was greeted with some amusement in Europe in view of our companies' huge investment there. He said that he also was

Aspects of European Direct Investments in the United States of America, papers presented at the Atlantic Council Conference, Washington, D.C., May 1969.

${ }^{20}$ See statement of William Person, Vice President, Business International, in Hearings Before the Subcomm. on Antitrust and Monopoly of the Senate Judiciary Comm. on Foreign Trade and the Antitrust Laws, 88th Cong., 2d Sess., pt. $x$, at 45 et seq. (1964).

${ }^{\text {so }}$ Ellis, supra note 28 .

s1 See, e.g., Continental Ore Co. v. Union Carbon \& Carbide Corp., 370 U.S. 690 (I962), and cases cited therein.

: See Hearings, supra note 29, at II9. 
unable to find a single American businessman in Europe who thought that this was true. ${ }^{33}$

While some observers have also said that "extraterritorial" antitrust enforcement is contrary to international law, the American Law Institute has agreed that the rule of the Alcoa case ${ }^{34}$ does not contravene international law and that a state may properly assert jurisdiction over acts abroad which have adverse effects in that country. ${ }^{35}$ Other countries and communities have also invoked such extraterritorial jurisdiction. $^{36}$ It is obvious that, as the Supreme Court noted in an early case, if neither country sought to regulate trade between them, then such trade would be entirely unregulated. ${ }^{37}$ Some extraterritorial enforcement is obviously necessary. It is also apparent that both countries have concurrent jurisdiction over their mutual trade, and this occasionally and understandably sometimes involves conflicts. Such conflicts, however, have fortunately been rare in antitrust enforcement. ${ }^{38}$

The great antitrust legislative movement in the last two decades (e.g., ECSC 1953, EEC 1957, Japan 1947, United Kingdom 1948, France 1953, Sweden r953, Germany 1957 , Spain 1963 ) has promoted a more uniform approach to restrictive business practices, both in domestic and in international trade. This very quickening in antitrust enforcement may, of course, mean that future conflicts will be between varying national antitrust laws and exemptions rather than between U.S. antitrust law and foreign law in some other field, such as occurred with contract rights in the ICI-BNS cases. $^{39}$

International cooperation, both to avoid conflicts and to coordinate national antitrust enforcement is provided for in a rg6y Recommendation of the OECD Council. ${ }^{40}$ This recommendation urges the member countries to notify and consult on national antitrust actions affecting another's important interests, to coordinate antitrust enforcement, and to exchange information on antitrust matters to the extent possible. The OECD Recommendation generally follows an informal U.S.-Canadian understanding, termed the "Fulton-Rogers Antitrust Notification Arrangement" arrived at in 1959 between then Minister of Justice Fulton and then Attorney General (now

\footnotetext{
${ }^{33}$ Proceedings of the Annual Meeting of ABA Section of Antitrust Law, Philadelphia, 1968, 37 ANtitRust L.J. 7r6, 733-35 (1969).

${ }^{34}$ United States v. Aluminum Co. of America, I48 F.2d 416, 443-44 (2d Cir. I945).

${ }^{36}$ Restatement (Second) of the Foreign Relations Law of the United States \$ I8 (1965).

${ }^{30}$ See Organization for Economic Cooperation and Development, Restrictive Business Practices - Comparattve Summart of Legislations in Europe and North America I4, 39 (1964); Fugate, Application of Antitrust Laws of the United States to International Trade-A Government Latuyer's View, I3 Prac. LaW. 25 (Ig67).

${ }^{37}$ United States v. Pacific \& Arctic Ry. \& Nav. Co., 228 U.S. 87, 106 (1913).

${ }^{38}$ See Timberg, Conflict and Growth in the International Law of Antitrust, 4 ABA SEc. INT'L \& Comp. L. BuLl. 20 (I960).

${ }^{30}$ United States v. Imperial Chem. Indus., Ltd., I00 F. Supp. 505 (S.D.N.Y. 1951), x05 F. Supp. 215 (S.D.N.Y. 1952); British Nylon Spinners, Ltd. v. Imperial Chem. Indus., Ltd., 2 All E.R. 780 (1953), final judgment, 3 All E.R. 88 (I954).

to See copy of this recommendation reprinted as appendix to Markert, Recent Developments in International Antitrust Cooperation, 13 ANTrrrusr BuLl. 355, 360-72 (I968).
} 
Secretary of State) Rogers. This arrangement has worked quite well on both sides. The U.S. State and Justice departments have been carrying out the general procedures suggested in the OCED Recommendation as to other countries as well as Canada for some time.

\section{IV}

\section{Clearance Procedures}

Clearance procedures under the U.S. antitrust laws have been mentioned. The Department of Justice has a "Business Review Procedure" under which if a company fully discloses in writing a proposed merger, joint venture, or other arrangement, domestic or foreign, which is feared may have antitrust consequences, the Department will, if feasible, attempt to state its intentions as to litigation should the arrangement be put into operation. The Federal Trade Commission has a Division of Advisory Opinions in its Bureau of Industry Guidance which likewise is available for such advice. As a last word, it is suggested that both American and foreign businessmen should seek and heed the advice of antitrust counsel before proceeding into ventures which may present antitrust problems. The extremely competent U.S. antitrust bar renders an invaluable service to the business community. Antitrust lawyers must also be given a large amount of credit for the general compliance with the antitrust laws by American business. 